\title{
Identification of Pseudomonas Isolates Associated With Bacterial Canker of Stone Fruit Trees in the Western Cape, South Africa
}

\author{
Khumbuzile N. Bophela, ${ }^{1}$ Yolanda Petersen, ${ }^{2}$ Carolee. T. Bull, ${ }^{3}$ and Teresa. A. Coutinho ${ }^{1, \dagger}$ \\ ${ }^{1}$ Department of Biochemistry, Genetics and Microbiology, Centre for Microbial Ecology and Genomics, Forestry and Agricul- \\ tural Biotechnology Institute, University of Pretoria, Hatfield 0028, Pretoria, South Africa \\ ${ }^{2}$ Crop Development Division, Agricultural Research Council, Infruitec-Nietvoorbij, Stellenbosch 7599, South Africa \\ ${ }^{3}$ Department of Plant Pathology and Environmental Microbiology, Pennsylvania State University, State College, PA 16801, \\ U.S.A.
}

\begin{abstract}
Bacterial canker is a common bacterial disease of stone fruit trees. The causal agents responsible for the disease include several pathovars in Pseudomonas syringae sensu lato and newly described Pseudomonas species. Pseudomonad strains were isolated from symptomatic stone fruit trees, namely apricot, peach, and plum trees cultivated in spatially separated orchards in the Western Cape. A polyphasic approach was used to identify and characterize these strains. Using a multilocus sequence typing approach of four housekeeping loci, namely cts, gapA, gyrB, and $r p o D$, the pseudomonad strains were delineated into two phylogenetic

pseudomonad strains were pathogenic on both apricot and plum seedlings, indicative of a lack of host specificity between Pseudomonas strains infecting Prunus spp. This is a first report of $P$. viridiflava isolated from plum trees showing symptoms of bacterial canker. $P$. viridiflava is considered to be an opportunistic pathogen that causes foliar diseases of vegetable crops, fruit trees, and aromatic herbs, and thus the isolation of pathogenic $P$. viridiflava from twigs of plum trees showing symptoms of bacterial canker suggests that this bacterial species is a potentially emerging stem canker pathogen of stone fruit trees in South Africa.
\end{abstract} groups within $P$. syringae sensu lato: $P$. syringae sensu stricto and Pseudomonas viridiflava. These results were further supported by LOPAT diagnostic assays and analysis of clades in the rep-PCR dendrogram. The
Keywords: Pseudomonas syringae, Pseudomonas viridiflava, stone fruit trees
Prunus species are of economic importance globally. Approximately $23 \%$ of cultivated land in South Africa is used to produce peaches, nectarines, apricots, and plums, with an estimated generated income of $\$ 1.89$ billion in stone fruit market sales. However, pests and diseases are two factors that have contributed to a reduction in stone fruit production and yield.

Bacterial canker is a commonly reported bacterial disease of stone fruit trees (Wilson 1953). The number of causal agents identified for this disease has increased dramatically in the past few decades, with majority being pathovars of Pseudomonas syringae or recently described Pseudomonas species. These include $P$. syringae pv. syringae (on Prunus spp.), P. syringae pv. avii (on Prunus avium), $P$. syringae pv. morprunorum (on P. avium and Prunus domestica), P. syringae pv. persicae (on Prunus spp.), and Pseudomonas cerasi (on P. avium) (Bultreys and Kaluzna 2010; Kałużna et al. 2016; Ménard et al. 2003; Roos and Hattingh 1983; Wilson 1953; Young 1988). The symptoms expressed by these hosts are blighting of dormant buds resulting in the formation of small cankers on twigs, branch and stem cankers, oozing or gummosis, branch and twig dieback, and occasionally complete tree death (Crosse 1966; Hattingh et al. 1989; Wilson 1953).

${ }^{\dagger}$ Corresponding author: T. A. Coutinho; teresa.coutinho@up.ac.za

Funding: This research was supported by the Hortgro Science research grant PL-16-UPP-PM01. K. N. Bophela received the NRF/DST Scarce Skills scholarship and the University of Pretoria doctoral bursary for the duration of her doctoral studies.

*The $\boldsymbol{e}$-Xtra logo stands for "electronic extra" and indicates that one supplementary figure and two supplementary tables are published online.

The author(s) declare no conflict of interest.

Accepted for publication 9 September 2019.

(C) 2020 The American Phytopathological Society
Pseudomonas syringae consists of a complex of strains that have a wide host range, which include herbaceous and woody crops as well as ornamental plants (Lamichhane et al. 2014, 2015). Pseudomonas syringae sensu lato is broadly defined as a bacterial group of species that cannot be distinguished phenotypically from $P$. syringae. Organisms in this group represent the majority of the fluorescent phytopathogenic pseudomonads (Young 1991). Currently, $>50$ pathovars are defined in this bacterial group (Bull et al. 2010).

The classification of organisms within $P$. syringae sensu lato (also referred to as the $P$. syringae species complex) involves phenotypic characterization, whereby physiological and biochemical properties are used to differentiate between pseudomonad strains, and genotypic characterization based on genome relatedness between strains in this complex. For example, repetitive element palindromic PCR (rep-PCR) is a rapid tool that has been used to identify strains into respective clonal lineages based on the similarity of their genomic structure (Louws et al. 1994). Pseudomonas syringae sensu lato was also delineated into nine genomospecies via DNA-DNA hybridization (Gardan et al. 1999), of which seven have been described and validly named: $P$. syringae (van Hall 1902), P. viridiflava (Burkholder 1930), P. amygdali (Psallidas and Pamagopoulos 1975), P. coronafaciens (Dutta et al. 2018), P. caricapapayae (Robbs 1956), P. avellanae (Janse et al. 1996), and $P$. cannabina (Gardan et al. 1999). The P. syringae species complex can also be delineated into 13 phylogenetic groups, comprising 23 subgroups, based on a multilocus sequence typing of four housekeeping genes (Berge et al. 2014). Many of the 13 phylogenetic groups described by Berge et al. 2014 represent the validly named species presented above and others (Bull and Koike 2015). Furthermore, the use of whole genome sequences has allowed a further delimitation of this bacterial group into 19 phylogenomic groups (Gomila et al. 2017).

The main objective of this study was to identify bacterial strains isolated from symptomatic twigs, leaves, and fruits of stone fruit trees in the Western Cape province of South Africa, using both phenotypic and genotypic methods. We also determined the 
pathogenicity of representative pseudomonad isolates on apricot and plum seedlings.

\section{Materials and Methods}

Sample collection and isolation of bacterial strains. A disease survey was undertaken in the Western Cape province of South Africa during the summer and spring seasons of 2014 to 2015 and 2016 to 2017 to assess the prevalence of bacterial canker of stone fruit trees in Bonnievale, Ceres, Franschhoek, Groot Drakenstein, Klapmuts, Montagu, Napier, Riviersonderend, Robertson, Simondium, Tulbagh, and Wellington. The samples collected were of diseased twigs, branches, and leaves of stone fruit trees (i.e., apricots, peaches, and plums). Typical bacterial canker symptoms observed were mainly gum oozing from closed buds, bark discoloration of branches, and leaves with shot holes (Fig. 1). The symptomatic plant materials were placed in brown paper bags and kept in a cold storage container with a temperature of $4^{\circ} \mathrm{C}$ until the samples were processed.

Isolations were made from symptomatic twigs and leaves as follows: small pieces of twigs and $5 \mathrm{~mm}^{2}$ of leaf tissue were surface sterilized in $10 \%$ (vol/vol) sodium hypochlorite solution for $1 \mathrm{~min}$ and $70 \%$ (vol/ vol) ethanol for $30 \mathrm{~s}$ and rinsed three times in sterile distilled water (Sabax Pour water, Adcock Ingram, South Africa). The leaf tissue was macerated in sterile $10 \mathrm{mM}$ of potassium phosphate buffer at $\mathrm{pH}$ 7.0 , and $30 \mu \mathrm{l}$ of the resulting suspension was streaked onto nutrient agar (NA) (Merck, Germany) and a semi-selective medium, King's B medium (KMB) (King et al. 1954). Small pieces of twigs, displaying internal discoloration of the tissue, were soaked in sterile distilled water for $1 \mathrm{~h}$ to allow the bacteria to exude from the cuttings into solution The resulting suspension was plated onto NA and KMB via the streak plate technique. All plates were incubated at $28^{\circ} \mathrm{C}$ for $48 \mathrm{~h}$.

Yellow fluorescent and nonfluorescent bacterial isolates on $\mathrm{KMB}$ were obtained. Pure cultures obtained by successive streaking of single colonies onto KMB (Supplementary Table S1) were stored at $-80^{\circ} \mathrm{C}$ in Microbank vials (Pro-Lab Diagnostics, Canada) containing $20 \%$ (vol/vol) glycerol until molecular and phenotypic characterization could be performed.

Phenotypic characterization via LOPAT diagnostic assays. Isolates from stone fruit trees were identified as $P$. syringae based on molecular analyses (multilocus sequence typing [MLST] and rep-PCR, described below). For a subset of these isolates, phenotypic characteristics were determined via LOPAT (levan production, oxidase activity, potato soft rot, arginine dihydrolase activity, tobacco hypersensitivity) diagnostic assays (Lelliott et al. 1966). For the levan production assay, nutrient agar plates supplemented with 5\% sucrose were prepared, and single colonies from pure cultures of pseudomonad strains from this study were streaked onto them and incubated at $28^{\circ} \mathrm{C}$ for 3 to 5 days. A positive reaction was considered to be the production of convex, white, domed, and mucoid colonies as a result of the action of the levan sucrase enzyme. The arginine dihydrolase assay involved stab-inoculating arginine medium $(1.0 \mathrm{~g}$ of peptone, $5.0 \mathrm{~g}$ of $\mathrm{NaCl}$, $0.3 \mathrm{~g}$ of $\mathrm{K}_{2} \mathrm{HPO}_{4}, 10.0 \mathrm{~g}$ of L-(+) arginine- $\mathrm{HCl}, 0.01 \mathrm{~g}$ of phenol red, and $15.0 \mathrm{~g}$ of agar; $\mathrm{pH}$ 7.2) with colonies of pseudomonad strains and sealing the inoculated area with mineral oil. The inoculated test tubes were incubated at $28^{\circ} \mathrm{C}$ for 24 to $48 \mathrm{~h}$. A positive reaction was

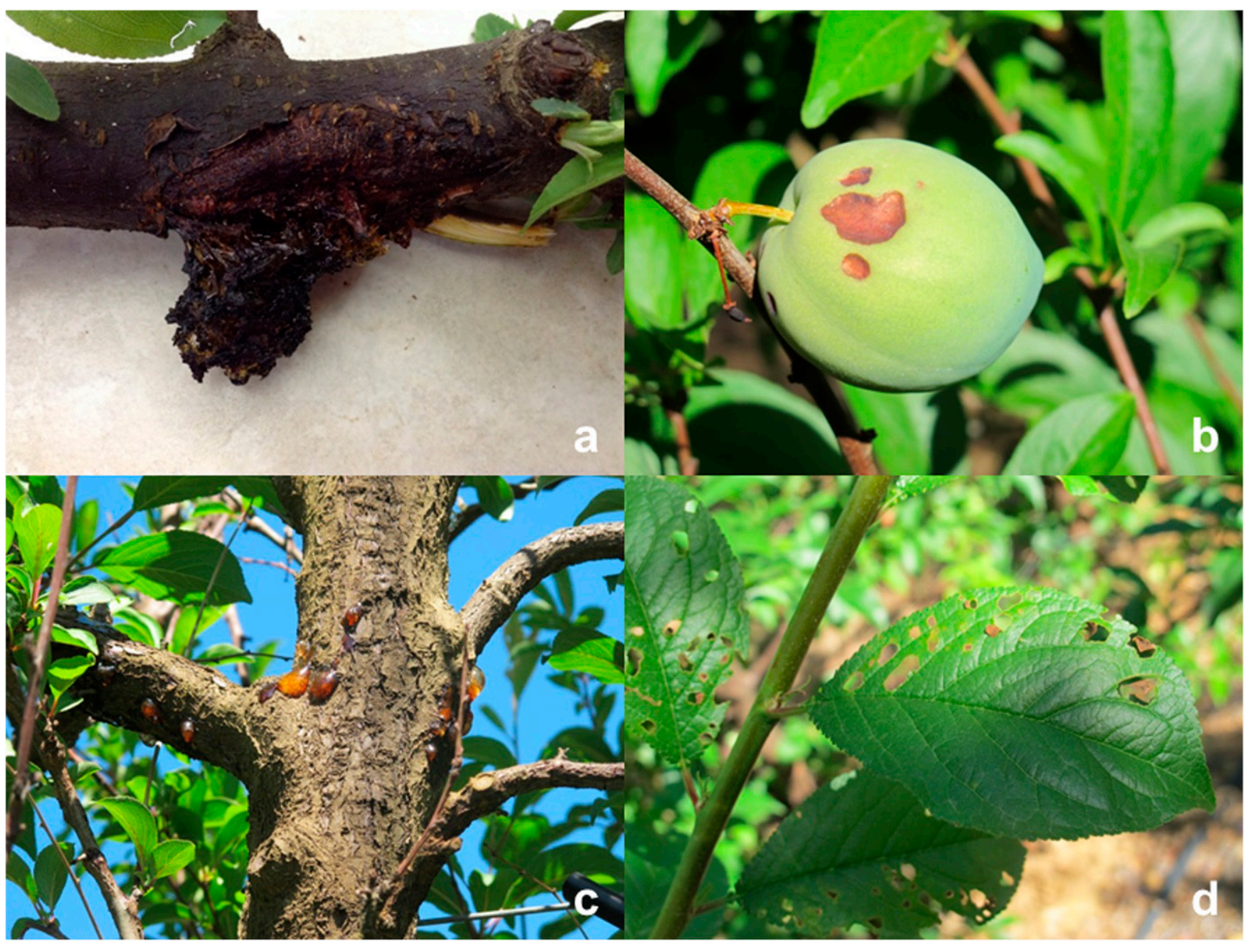

Fig. 1. Characteristic symptoms of bacterial canker on stone fruit trees. $\mathbf{a}$, Blighting of dormant buds resulting in the formation of small cankers at the base of the bud; $\mathbf{b}$, dark brown to black sunken lesions develop on the fruit with irregularly shaped margins; $\mathbf{c}$, branch and stem cankers accompanied by gummosis; $\mathbf{d}$, watersoaked leaf spots that later become necrotic and fall out, resulting in a characteristic shot-hole appearance. 
determined by a change in color from yellow to red/pink. In the potato soft rot assay, 8-mm-thick potato slices were cut from peeled whole potato tubers that were sterilized in $70 \%$ ( $\mathrm{vol} / \mathrm{vol})$ ethanol before peeling. The potato slices were placed on top of plastic films inside two mediumsized plastic containers that were lined with moistened paper towels. The potato slices were stab-inoculated with single colonies of pseudomonad strains with sterilized toothpicks. The inoculated potato slices were left to incubate at room temperature inside the containers for 24 h. Decayed potato tissue was observed as water-soaking that extended beyond the site of inoculation. To determine the ability of the pseudomonad strains to induce a hypersensitive reaction, tobacco (Nicotiana tabacum) seedlings that were grown from seeds were inoculated with bacterial inocula prepared in $10 \mathrm{mM}$ of phosphate buffer, resulting in final concentrations of $1 \times 10^{8} \mathrm{CFUs} / \mathrm{ml}$. The tobacco leaves were infiltrated with bacterial suspension by using a blunt end of a 1-ml syringe. Three leaves were infiltrated per pseudomonad strain.

DNA extraction and $16 \mathrm{~S} r \boldsymbol{R} N A$ sequencing. Genomic DNA was extracted from single colonies of bacterial strains that were stored at $-80^{\circ} \mathrm{C}$ by using the Quick-gDNA MiniPrep DNA extraction kit (Zymo Research, Inqaba Biotech, South Africa) according to the manufacturer's instructions. The quality and quantity of the DNA were verified via gel electrophoresis and spectrophotometry, respectively. The small ribosomal subunit was amplified for each bacterial strain with previously described universal primers 27F (5'-GAGTTTGATCC TGGCTCAG-3') and 1429R (5'-GGTTACCTTGTTACGACT-3') (Supplementary Table S2) (Lane 1991). In each 25- $\mu 1$ reaction, the final concentrations were as follows: $1 \times$ reaction buffer, $2.0 \mathrm{mM}$ of $\mathrm{MgCl}_{2}, 200 \mu \mathrm{M}$ of each nucleotide (dATP, dGTP, dTTP, and dCTP) (Thermo Fisher Scientific, U.S.A.), $0.2 \mu \mathrm{M}$ of each primer (Inqaba Biotech, South Africa), and 1.5 U Supertherm Taq polymerase (JMR Holdings, London) added to sterile distilled water, and as final step 10 to $50 \mathrm{ng}$ of template DNA was added to the reaction mix. The cycle conditions were as previously described by Hongoh et al. (2003), with modifications made to the conditions. The initial denaturation was $94^{\circ} \mathrm{C}$ for $10 \mathrm{~min}$, followed by 30 cycles of denaturation at $94^{\circ} \mathrm{C}$ for $1 \mathrm{~min}$, annealing at $55^{\circ} \mathrm{C}$ for $1 \mathrm{~min}$, elongation at $72^{\circ} \mathrm{C}$ for $1 \mathrm{~min}$, and a final elongation step at $72^{\circ} \mathrm{C}$ for $5 \mathrm{~min}$.

The amplified products were visualized on a $1 \%$ (wt/vol) agarose gel and purified with the exonuclease-alkaline phosphatase (Thermo Scientific, U.S.A.) enzyme reaction mix. The resulting purified amplicons were sequenced on a genetic analyzer (Thermo Fisher Scientific) at the DNA sequencing facility at the University of Pretoria (South Africa) using only the forward primer, 27F, for rapid identification at the genus level.

The sequence data of the small ribosomal subunit of the bacterial isolates were manually edited in Chromas version 2.6.4 (Technelysium Pty Ltd, Australia). The partial sequences for the $16 \mathrm{~S} r R N A$ gene region were compared against the references in the GenBank database with the BLAST tool (National Centre for Biotechnology Information [NCBI], U.S.A.). The BLAST search hits of $99 \%$ sequence similarity and E-values of zero were the criteria used to allocate the bacterial isolates into their respective genera (Supplementary Table S1).

Genotypic characterization via MLST. To place the pseudomonad isolates into their respective phylogroups (Berge et al. 2014), multilocus sequence typing of four housekeeping loci, namely, cts, gapA, gyrB, and $r p o D$, was conducted with previously described primers (Hwang et al. 2005; Parkinson et al. 2011; Sarkar and Guttman 2004) (Supplementary Table S2). The final concentrations in each $25-\mu 1$ reaction were as follows: $1 \times$ reaction buffer, $2.0 \mathrm{mM}$ of $\mathrm{MgCl}_{2}$, $200 \mu \mathrm{M}$ of each nucleotide (dATP, dGTP, dTTP, and dCTP), $0.2 \mu \mathrm{M}$ of each primer (Inqaba Biotech), and 1.5 U of Supertherm Taq polymerase (JMR Holdings, London) added to sterile distilled water, and as a final step 10 to $50 \mathrm{ng} / \mu \mathrm{l}$ of template DNA was added to the reaction mix. The cycle conditions were as previously described (Sarkar and Guttman 2004), with modifications as follows: initial denaturation at $94^{\circ} \mathrm{C}$ for $2 \mathrm{~min}, 30$ cycles of denaturation at $95^{\circ} \mathrm{C}$ for $30 \mathrm{~s}$, annealing at varying temperatures for $1 \mathrm{~min}$, and elongation at $72^{\circ} \mathrm{C}$ for $1 \mathrm{~min}$. The annealing temperature varied for each locus, that is, $55^{\circ} \mathrm{C}$ for gyrB and $r p o D, 56^{\circ} \mathrm{C}$ for $c t s$, and $62^{\circ} \mathrm{C}$ for gapA. A further extension step was added at $72^{\circ} \mathrm{C}$ for $5 \mathrm{~min}$.
The purification of amplified products, sequencing, and sequence editing were as described earlier. Because both orientations were sequenced for each locus, consensus sequences were obtained from the forward and reverse sequences of each pseudomonad strain in MEGA 7 (Kumar et al. 2016). The consensus sequences were compared against reference sequences in the GenBank database in BLAST. A multi-sequence alignment including the partial sequences of pseudomonad strains from this study together with sequences of reference strains in $P$. syringae sensu lato retrieved from the Plant Associated and Environmental Microbes Database (PAMDB, http:// genome.ppws.vt.edu/cgi-bin/MLST/home.pl) was performed with the CLUSTALW algorithm of the online version of MAFFT (Katoh et al. 2002; Katoh and Standley 2013) with default settings. The resulting multi-sequence alignment was exported to BioEdit version 7.0.9.0 (Hall 1999), and overhangs on both ends of the sequences were trimmed. The partial sequences of the three additional loci were 476, 502, and 371 nucleotides (nt) in length. The partial sequences of four protein-coding genes were used to generate a concatenated dataset, which was based on the results of a partition homogeneity test elucidating their congruency $(P>0.05)$. A maximum likelihood phylogeny was constructed from the concatenated dataset of $1,600 \mathrm{nt}$ in sequence length. Maximum likelihood phylogenies of sequences of the four protein-coding genes and concatenated dataset were constructed in MEGA 7 (Kumar et al. 2016), applying the general time reversible model with a proportion of invariable sites and rate variation between sites. Bootstrap analysis of 1,000 replicates was performed for each maximum likelihood analysis to estimate the level of support at each node.

Genotypic characterization using rep-PCR. To determine genetic variability, the pseudomonad strains from symptomatic twigs of stone fruit trees were compared with the different pathotype strains of $P$. syringae sensu stricto and $P$. viridiflava (Table 1 ) with repPCR. The BOX, ERIC, and REP elements were amplified with previously described primers (Supplementary Table S2) (Versalovic et al. 1991, 1994). Each 20- $\mu$ l reaction comprised the following: $10 \mu \mathrm{l}$ of $2 \times$ GoTaq Green Master Mix (Promega, Madison, WI, U.S.A.), $1.0 \mu \mathrm{M}$ of each primer pair, for ERIC and REP primers, and 2.0 $\mu \mathrm{M}$ of the BOX primer (Inqaba Biotech) (Supplementary Table S2) and $20 \mathrm{ng}$ template DNA were added to nuclease-free water (Invitrogen, Life Technologies, U.K.). The cycle conditions for all primer sets, except for BOXA1R, used as a single primer in the reactions, were as previously described by Rademaker et al. (1998). The reactions were visualized via agarose electrophoresis according to the protocol by Rademaker et al. (1998) with slight modifications, which included conducting electrophoresis for approximately $4 \mathrm{~h}$ at a constant voltage of $60 \mathrm{~V}, 25$ to $30 \mathrm{~mA}$ with a $2 \%$ (wt/vol) agarose gel. The banding patterns resulting from the DNA fragments were visualized, and the dendrograms were generated in Bionumerics version 6.6 (bioMérieux, Belgium) using the unweighted pair group method with arithmetic mean clustering algorithm based on the degree of similarity between the genotypic fingerprints of the pseudomonad strains. The pairwise comparisons were calculated via Jaccard's similarity coefficient (Jaccard 1901).

Pathogenicity assays on $P$. domestica (Plum) and Prunus armeniaca (Apricot) seedlings. Prunus domestica cultivars 'Sapphire' and 'Songold' and P. armeniaca cultivar 'Soldonna' were sourced as certified pathogen-free 1-year-old scions grafted onto Maridon rootstock, from a nursery (Stemmet Kwekery, Montagu, SA). The seedlings were planted in loamy soil in 30-cm pots (Plastilon, Pretoria, SA). The seedlings were kept in a greenhouse at the Hatfield Experimental Farm (University of Pretoria, $25^{\circ} 47^{\prime} 7.38^{\prime \prime} \mathrm{S}, 28^{\circ} 15^{\prime} 30.44^{\prime \prime} \mathrm{E}$ ). The temperature in the greenhouse was approximately $28^{\circ} \mathrm{C}$ with natural day/night cycles, usually $13 \mathrm{~h}$ day and $11 \mathrm{~h}$ night conditions in summer. Supplementing of nutrients of the seedlings was done once per week with an organic fertilizer containing $80 \mathrm{~g} / \mathrm{kg}$ of N, $20 \mathrm{~g} / \mathrm{kg}$ of P, and $58 \mathrm{~g} / \mathrm{kg}$ of K (4:1:3) (Nitrosol, Efekto, SA).

The ability of the pseudomonad strains to cause disease was elucidated through pathogenicity assays performed under glasshouse conditions. Eleven representative strains were selected based on the host of origin (in our study we focused mainly on those isolated from 
symptomatic plum trees but included some strains isolated from symptomatic apricot trees) and the different clades within $P$. syringae sensu lato that were identified in this study, namely, BV14-1 and A002 (phylogroup 2d), BDAP12 and BV14-2 (phylogroup 2b), K005(3)1, K005(3)2d and R11-1(phylogroup 2a), R13-1, K005(3) 1c, and Pm005 and K005(2)2e (phylogroup 7a). A comprehensive list of strains used in this study is shown in Table 1.

The preparation of bacterial inocula and inoculation of trees was performed as previously described by Hulin et al. (2018) 3 months after planting. Single colonies of pure cultures of each representative Pseudomonas isolate were grown in nutrient broth (Merck) in $100-\mathrm{ml}$ volumetric flasks and placed in a shaking incubator at $150 \mathrm{rpm}$ for $18 \mathrm{~h}$. The bacterial suspensions were adjusted to a concentration of $2 \times 10^{7} \mathrm{CFUs} / \mathrm{ml}\left(\mathrm{OD}_{600}\right.$ approximately 0.02$)$ with sterile $10-\mathrm{mM}$ phosphate buffer. Whole trees were inoculated through stem wounding, whereby superficial wounds were created from the trunks of the trees with sterile scalpels and $200 \mu \mathrm{l}$ of inoculum pipetted into the wounds. The inoculated wounds were sealed with self-sealing film and covered with masking tape. Three trees of each cultivar were inoculated per representative strain. Trees inoculated with sterile $10-\mathrm{mM}$ phosphate buffer served as negative controls. The inoculated seedlings were kept in the greenhouse under $13 \mathrm{~h}$ day and $11 \mathrm{~h}$ night conditions at $65 \%$ relative humidity for approximately 2 months before the pathogenicity trial was terminated.
Reisolation procedure. Reisolation of bacteria was done from the leading edges of lesions on the main stem of apricot and plum seedlings. Small pieces of apricot tissue were directly plated onto KMB, or in the case of plums, tissue was macerated in 10-mM phosphate buffer, after surface sterilization in $10 \%$ (vol/vol) sodium hypochlorite and rinsed three times in sterile distilled water with a mortar and pestle. A volume of $30 \mu \mathrm{l}$ of the resulting suspension was streaked onto KMB. All plates were incubated at $28^{\circ} \mathrm{C}$ for $48 \mathrm{~h}$.

Bacteria exuding from the symptomatic pieces of apricot tissue were subcultured onto new plates of KMB via a streak-plate technique and incubated as previously described. Single colonies, suspended in sterile distilled water, of bacterial isolates recovered from apricots and plums were analyzed via rep-PCR of the BOX element together with the original inoculum strain. The similarity of the banding patterns of the recovered isolates and inoculum strain were compared visually.

\section{Results}

Phenotypic characterization via LOPAT diagnostic assays. Pseudomonad strains isolated from symptomatic stone fruit trees were characterized with the five determinative tests previously described (Lelliott et al. 1966): levan production, oxidase reaction, pectolytic activity on potato, arginine dihydrolase activity, and hypersensitivity response on tobacco. Based on these tests, the majority of the pseudomonad strains in this study were found to have similar characteristics as LOPAT group 1a strains, $P$. syringae pv.

Table 1. List of strains isolated from symptomatic twigs of stone fruit trees in the Western Cape province and reference type and pathotype strains of $P$. syringae and P. viridiflava ${ }^{\mathrm{a}}$

\begin{tabular}{|c|c|c|c|c|c|c|}
\hline Species & Strain ID & Host & Year & Location & $\begin{array}{l}\text { MLSA } \\
\text { group }\end{array}$ & Citation \\
\hline \multirow[t]{15}{*}{ Pseudomonas syringae } & ABD007 & Prunus armeniaca & 2014 & Simondium & $2 d$ & This study \\
\hline & A001 & P. armeniaca & 2014 & Simondium & $2 d$ & This study \\
\hline & $\mathrm{A} 002$ & P. armeniaca & 2014 & Simondium & $2 d$ & This study \\
\hline & $\mathrm{A} 012$ & P. armeniaca & 2014 & Simondium & $2 d$ & This study \\
\hline & A019 & P. armeniaca & 2014 & Simondium & $2 b$ & This study \\
\hline & BDAP12 & P. armeniaca & 2015 & Simondium & $2 b$ & This study \\
\hline & BV14-1 & P. domestica & 2017 & Simondium & $2 d$ & This study \\
\hline & BV14-2 & P. domestica & 2017 & Simondium & $2 b$ & This study \\
\hline & K005(3)1 & P. domestica & 2016 & Simondium & $2 \mathrm{a}$ & This study \\
\hline & $\mathrm{K} 005(3) 2 \mathrm{a}$ & P. domestica & 2016 & Simondium & $2 \mathrm{a}$ & This study \\
\hline & $\mathrm{K} 005(3) 2 \mathrm{~d}$ & P. domestica & 2016 & Simondium & $2 \mathrm{a}$ & This study \\
\hline & PL002 & P. persica & 2014 & Simondium & $2 d$ & This study \\
\hline & R11-1(A) & P. domestica & 2017 & Simondium & $2 a$ & This study \\
\hline & R11-1(B) & P. domestica & 2017 & Simondium & $2 \mathrm{a}$ & This study \\
\hline & $\mathrm{R} 11-1(\mathrm{C})$ & P. domestica & 2017 & Simondium & $2 \mathrm{a}$ & This study \\
\hline \multirow[t]{7}{*}{ Pseudomonas viridiflava } & $\mathrm{K} 005(2) 2 \mathrm{e}$ & P. domestica & 2016 & Simondium & $7 \mathrm{a}$ & This study \\
\hline & $\mathrm{K} 005(3) 1 \mathrm{a}$ & P. domestica & 2016 & Simondium & $7 \mathrm{a}$ & This study \\
\hline & $\mathrm{K} 005(3) 1 \mathrm{~b}$ & P. domestica & 2016 & Simondium & $7 \mathrm{a}$ & This study \\
\hline & $\mathrm{K} 005(3) 1 \mathrm{c}$ & P. domestica & 2016 & Simondium & $7 \mathrm{a}$ & This study \\
\hline & Pm005 & P. domestica & 2014 & Groot Drakenstein & $7 \mathrm{a}$ & This study \\
\hline & Pm006 & P. domestica & 2014 & Groot Drakenstein & $7 \mathrm{a}$ & This study \\
\hline & R13-1 & P. domestica & 2017 & Simondium & $7 \mathrm{a}$ & This study \\
\hline P. syringae pv. syringae ${ }^{\mathrm{T}}$ & CFBP1392 & Syringa vulgaris & 1902 & U.K. & $2 b$ & van Hall 1902 \\
\hline P. viridiflava ${ }^{\mathrm{T}}$ & CFBP2107 & Phaseolus vulgaris & 1927 & Switzerland & 8 & Billing 1970 \\
\hline P. syringae $\mathrm{pv}$. dysoxyli ${ }^{\mathrm{PT}}$ & CFBP2356 & Dysoxylum spectabile & 1949 & New Zealand & $2 \mathrm{a}$ & Hutchinson 1949; Young et al. 1978 \\
\hline P. syringae pv. pisi $\mathrm{PT}^{\mathrm{PT}}$ & NCPPB 2585 & Pisum sativum & 1916 & New Zealand & $2 \mathrm{~b}$ & Sackett 1916; Young et al. 1978 \\
\hline P. syringae pv. coryli $\mathrm{PT}^{\mathrm{T}}$ & NCPPB 4273 & Corylus avellana & 2001 & Italy & $2 \mathrm{~b}$ & Scortichini et al. 2005 \\
\hline P. congelans ${ }^{\mathrm{T}}$ & CFBP21466 & Phyllosphere grass & 2001 & Germany & $2 \mathrm{c}$ & Behrendt et al. 2003 \\
\hline P. syringae pv. solidagae ${ }^{\mathrm{PT}}$ & ICMP16925 & Solidago altissima & 1998 & Japan & $2 \mathrm{~d}$ & Sato et al. 2001 \\
\hline P. syringae $\mathrm{pv}$. aptata $\mathrm{PT}$ & CFBP1617 & Beta vulgaris & 1913 & U.S.A. & $2 b$ & Brown and Jamieson 1913; Young et al. 1978 \\
\hline $\begin{array}{l}\text { P. syringae } \mathrm{pv} . \\
\text { atrofaciens }\end{array}$ & CFBP2213 & Triticum aestivum & 1920 & New Zealand & $2 b$ & McCulloch 1920; Young et al. 1978 \\
\hline P. syringae pv. aceris ${ }^{\mathrm{PT}}$ & CFBP2339 & Acer palmatum & 1939 & Japan & $2 d$ & Ark 1939; Young et al. 1978 \\
\hline P. syringae pv. lapsa ${ }^{\mathrm{PT}}$ & CFBP1731 & Zea mays & 1940 & New Zealand & $2 \mathrm{~b}$ & Ark 1940; Young et al. 1978 \\
\hline P. syringae pv. papulans ${ }^{\mathrm{PT}}$ & LMG5076 & Malus pumila & 1917 & U.S.A. & $2 \mathrm{a}$ & Rose 1917; Dhanvantari 1977 \\
\hline P. syringae pv. syringae & B728a & Phaseolus vulgaris & 1987 & U.S.A. & $2 d$ & Loper and Lindow 1987 \\
\hline P. syringae pv. tomato ${ }^{\mathrm{C}}$ & DC3000 & Solanum lycopersicum & 1933 & U.S.A. & $1 \mathrm{a}$ & Young et al. 1978; Cuppels 1986 \\
\hline
\end{tabular}

a Type strains are denoted by superscript T, pathotype strains are denoted by superscript PT, and alternative synonymous nomenspecies within a given genomospecies are denoted with a superscript $\mathrm{C}$. 
syringae B728a and P. syringae pv. tomato DC3000 (supplied by Dr Carrie Brady, University of the West of England, Bristol, U.K.). (Table 2), except for ABD007, PL002, R11-1(A), and R11-1(B) strains, which had varied reactions of arginine dihydrolase activity. Additionally, three pseudomonad strains, BDAP12, BV14-2, and K005(3)1, were nonfluorescent on KMB, similar to the $P$. syringae pv. syringae B728a isolate used in this study.

Seven of the pseudomonad strains had similar phenotypic traits as LOPAT group II strains previously reported by Lelliott et al. (1966). Two of the seven strains, Pm005 and R13-1, displayed varied reactions of arginine dihydrolase activity (Table 2), comparable to some of the LOPAT group 1a strains. Interestingly, four of the strains, K005(2)2e, K005(3)1a, K005(3)1b, and K005(3)1c, did not induce a hypersensitive response on tobacco leaves but showed pectolytic activity on potato slices (Table 2). Also, five of the LOPAT group II strains, K005(2)2e, K005(3)1a, K005(3)1b, Pm005, and Pm006, did not fluoresce on KMB.

Genotypic characterization via $16 \mathrm{~S} r R N A$ sequencing and MLST. Of the 118 bacterial strains that were isolated from symptomatic stone fruit trees, 41 were identified as Pseudomonas based on the similarity of $99 \%$ of their partial $16 \mathrm{~S} r R N A$ sequences with reference sequences in the GenBank database (Supplementary Table S1). The remaining isolates were identified as various other bacterial genera, viz. Pantoea (32), Bacillus (17), Erwinia (8), Curtobacterium (7), Xanthomonas (2), Paenibacillus (2), Yersinia (2), Psychrobacillus (1), Nocardiodes (1), Brevibacillus (1), Arthrobacter (1), Microbacterium (1), and Variovorax (1). Partial sequences of query length 291 nt of the cts gene revealed that 20 of the 41 Pseudomonas strains were potential $P$. syringae strains and eight were potential $P$. viridiflava strains based on $99 \%$ sequence similarity with reference sequences in the GenBank database (Supplementary Table S1). Three housekeeping genes were sequenced, namely gapA, gyrB, and $r p o D$, in

Table 2. Phenotypic characterization of Pseudomonas isolates obtained from symptomatic twigs of stone fruit trees in the Western Cape province, South Africa $^{\mathrm{a}}$

\begin{tabular}{|c|c|c|c|c|c|c|c|}
\hline Strain ID & Group no. & $\mathbf{L}$ & $\mathbf{O}$ & $\mathbf{P}$ & $\mathbf{A}$ & $\mathbf{T}$ & $\begin{array}{c}\text { Fluorescent } \\
\text { on KB }\end{array}$ \\
\hline ABD007 & Ia & + & - & - & $+1-$ & + & + \\
\hline A001 & Ia & + & - & - & - & + & + \\
\hline A002 & Ia & + & - & - & - & + & + \\
\hline A012 & Ia & + & - & - & - & + & + \\
\hline A019 & Ia & + & _- & - & - & + & + \\
\hline BDAP12 & Ia & + & - & - & - & + & - \\
\hline BV14-1 & Ia & + & - & - & - & + & + \\
\hline BV14-2 & Ia & + & - & - & - & + & - \\
\hline $\mathrm{K} 005(2) 2 \mathrm{e}$ & II & + & - & + & - & - & - \\
\hline K005(3)1 & Ia & + & - & - & - & + & - \\
\hline K005(3)1a & II & + & - & + & + & - & - \\
\hline $\mathrm{K} 005(3) 1 \mathrm{~b}$ & II & + & - & + & + & - & - \\
\hline $\mathrm{K} 005(3) 1 \mathrm{c}$ & II & + & - & + & - & - & + \\
\hline $\mathrm{K} 005(3) 2 \mathrm{a}$ & Ia & + & - & - & - & + & + \\
\hline $\mathrm{K} 005(3) 2 \mathrm{~d}$ & Ia & + & - & - & - & + & + \\
\hline PL002 & Ia & + & - & - & $+/-$ & + & + \\
\hline Pm005 & II & + & - & + & $+1-$ & + & - \\
\hline Pm006 & II & + & - & + & - & + & - \\
\hline R11-1(A) & Ia & + & - & - & $+/-$ & + & + \\
\hline R11-1(B) & Ia & + & - & - & $+1-$ & + & + \\
\hline R11-1(C) & Ia & + & - & - & - & + & + \\
\hline $\mathrm{R} 13-1$ & II & + & - & + & $+/-$ & + & + \\
\hline P. viridiflava $\mathrm{CFBP} 2107^{\mathrm{Ty}}$ & II & - & - & + & - & + & + \\
\hline Ps. pv. syringae $\mathrm{B} 728 \mathrm{a}^{\mathrm{z}}$ & Ia & + & - & - & - & + & - \\
\hline Ps. pv. tomato DC $3000^{\mathrm{z}}$ & Ia & + & - & - & - & + & + \\
\hline
\end{tabular}

a + indicates a positive reaction; - indicates a negative reaction; A, arginine dihydrolase; L, levan; O, oxidase; $\mathrm{P}$, potato soft rot; T, hypersensitive response on Nicotiana tabacum; ${ }^{\mathrm{y}}$, positive control for LOPAT group II ( $P$. viridiflava); ${ }^{\mathrm{z}}$, positive control for LOPAT group 1a (P. syringae). P. syringae pv. syringae $\mathrm{B} 728 \mathrm{a}$ and $P$. syringae pv. tomato DC3000 isolates were supplied by Dr. Carrie Brady (University of the West of England, Bristol, United Kingdom). addition to the $c t s$ gene, for the strains that were identified as potential $P$. syringae and $P$. viridiflava (Supplementary Table S1).

In the concatenated phylogeny, the taxonomic positions of the pseudomonad strains in this study were determined within $P$. syringae sensu lato. The pseudomonad strains in this study were delineated into two major groups, namely, $P$. syringae sensu stricto (phylogroup 2) and P. viridiflava (phylogroup 7) (Fig. 2). The majority of the pseudomonad strains grouped in three phylogroup 2 clades (i.e., phylogroups $2 \mathrm{a}, 2 \mathrm{~b}$, and $2 \mathrm{~d}$ ). A few strains clustered in a single clade in phylogroup 7a.

Phylogroup 2a (PG02a) strains included K005(3)1, K005(3)2a, K005(3)2d, R11-1(A), R11-1(B), and R11-1(C), which clustered with strain PsyCit7, isolated from an asymptomatic orange tree (Fig. 2). Three $P$. syringae strains, A019, BDAP12, and BV14-2, grouped in phylogroup $2 \mathrm{~b}$ together with $P$. syringae pvs. avellanae PavIsaPave013 and pisi H5E1 (Fig. 2). Five P. syringae strains, A001, A002, ABD007, BV14-1, and PL002, grouped in phylogroup 2d in the same groups as three $P$. syringae pv. syringae strains: $\mathrm{B} 728 \mathrm{a}$ (bean), HGI-W 7872 (plum), and CC0301 (cantaloupe) (Fig. 2).

A $P$. syringae strain from apricot, A012, grouped as a singleton on a separate branch adjacent to the phylogroup $2 \mathrm{~d}$ clade. The remaining seven pseudomonad strains, K005(2)2e, K005(3)1a, K005(3)1b, K005(3)1c, Pm005, Pm006, and R13-1, were in the phylogroup 7a clade with a $P$. viridiflava strain, BSO02, which was isolated from a Kiwi tree showing symptoms of bacterial canker (Fig. 2). Interestingly, these strains were isolated on three separate occasions, only from plum trees on farms located close to each other (Table 1).

Genotypic characterization via rep-PCR. We performed repPCR of BOX, ERIC, and REP elements for the pseudomonad strains isolated from symptomatic stone fruit trees. The clustering of the pseudomonad isolates in the BOX-PCR fingerprint profiles were not congruent to that of the MLSA, that is, the pseudomonad strains in this study did not cluster with members of the same phylogroup but rather clustered by relatedness of their fingerprint profiles (Fig. 3). However, there were a few exceptions whereby clustering was based on phylogroup. For example, the majority of the $P$. viridiflava (phylogroup 7a) strains except for R13-1 and CFBP $2107^{\mathrm{T}}$ clustered in the same clade and were more closely related to $P$. syringae $\mathrm{CFBP} 1392^{\mathrm{T}}$ (94\% similarity) (Fig. 3). Interestingly, the topology of the $P$. viridiflava strains in this clade was congruent to that of the MLSA (Fig. 2).

Similarly, the topology of two of the phylogroup 2a strains, R111a and R11-1b, was shown to be congruent to their topology in the MLSA. However, these strains clustered with phylogroup 2d strains, A001, ABD007, and B728a (Fig. 3, 94\% similarity), in the BOXPCR dendrogram. Additionally, the other phylogroup $2 \mathrm{~d}$ strains, A002, BV14-1, and PL002, were closely related to P. syringae pv. lapsa $\mathrm{CFBP} 1731^{\mathrm{PT}}$, a pathotype of phylogroup $2 \mathrm{~b}$, rather than pathotypes in the same phylogroup, $P$. syringae pvs. aceris CFBP2339 ${ }^{\mathrm{PT}}$ and solidagae ICMP16925 ${ }^{\mathrm{PT}}$ (Fig. 3).

In contrast to the BOX-PCR fingerprint profiles (Fig. 3), the topology of the ERIC-PCR fingerprint profiles was congruent with that of the MLSA for two of the phylogroups previously identified (Fig. 4). The clustering of pseudomonad strains reflected genome relatedness for $P$. syringae sensu stricto and $P$. viridiflava. However, the clustering of the remainder of the pseudomonad and reference strains reflected the similarity of the fingerprint patterns.

All strains identified as phylogroup 2a strains, K005(3)1, K005(3)2a, K005(3)2d, R11-1a, R11-1b, and R11-1c, formed a separate cluster from known pathotype strains in $P$. syringae sensu stricto (Fig. 4, 83\% similarity). Furthermore, the $P$. viridiflava strains split into two clusters, wherein both clusters were distantly related to the $P$. viridiflava type strain $\mathrm{CFBP} 2107^{\mathrm{T}}$. The first cluster comprised K005(2)2e, K005(3)1a, K005(3)1b, and K005(3)1c, and the second cluster included Pm005, Pm006, and R13-1. The second cluster was more closely related to a phylogroup $2 \mathrm{~d}$ pathotype, $P$. syringae pv. aceris CFBP2339 ${ }^{\mathrm{PT}}$ (Fig. $4,82 \%$ similarity) than to other $P$. viridiflava strains and the type strain CFBP $2107^{\mathrm{T}}$. Interestingly, the topology of the strains in the respective clades was congruent to the topology of the $P$. viridiflava clade in the MLSA but only when combined (Fig. 2). 
Likewise, the topology of the REP-PCR fingerprint profiles was congruent to the topology of three of the phylogroups in the MLSA (Fig. 2; phylogroups 2a, 2d, and 7a). All phylogroup 2a strains, with the exception of pathotype $P$. syringae pv. dysoxyli CFBP $2356^{\mathrm{PT}}$, clustered together on a separate clade with $81 \%$ similarity (Fig. 5). Also, the majority of $P$. viridiflava strains clustered together, except Pm006, which was more closely related (100\% similarity) to pathotypes $P$. syringae pv. solidagae ICMP16925 ${ }^{\mathrm{PT}}$ and $P$. syringae pv. lapsa CFBP1731 ${ }^{\mathrm{PT}}$, both $P$. syringae sensu stricto strains.

Despite the $P$. viridiflava strains sharing a $91 \%$ similarity, these strains formed two subgroups within this clade (Fig. 5). The first subgroup contained K005(2)2e, K005(3)1a, and K005(3)1b with close relatedness of $98 \%$ similarity. The second subgroup comprised Pm005, R13-1, and K005(3)1c, which were more closely related to

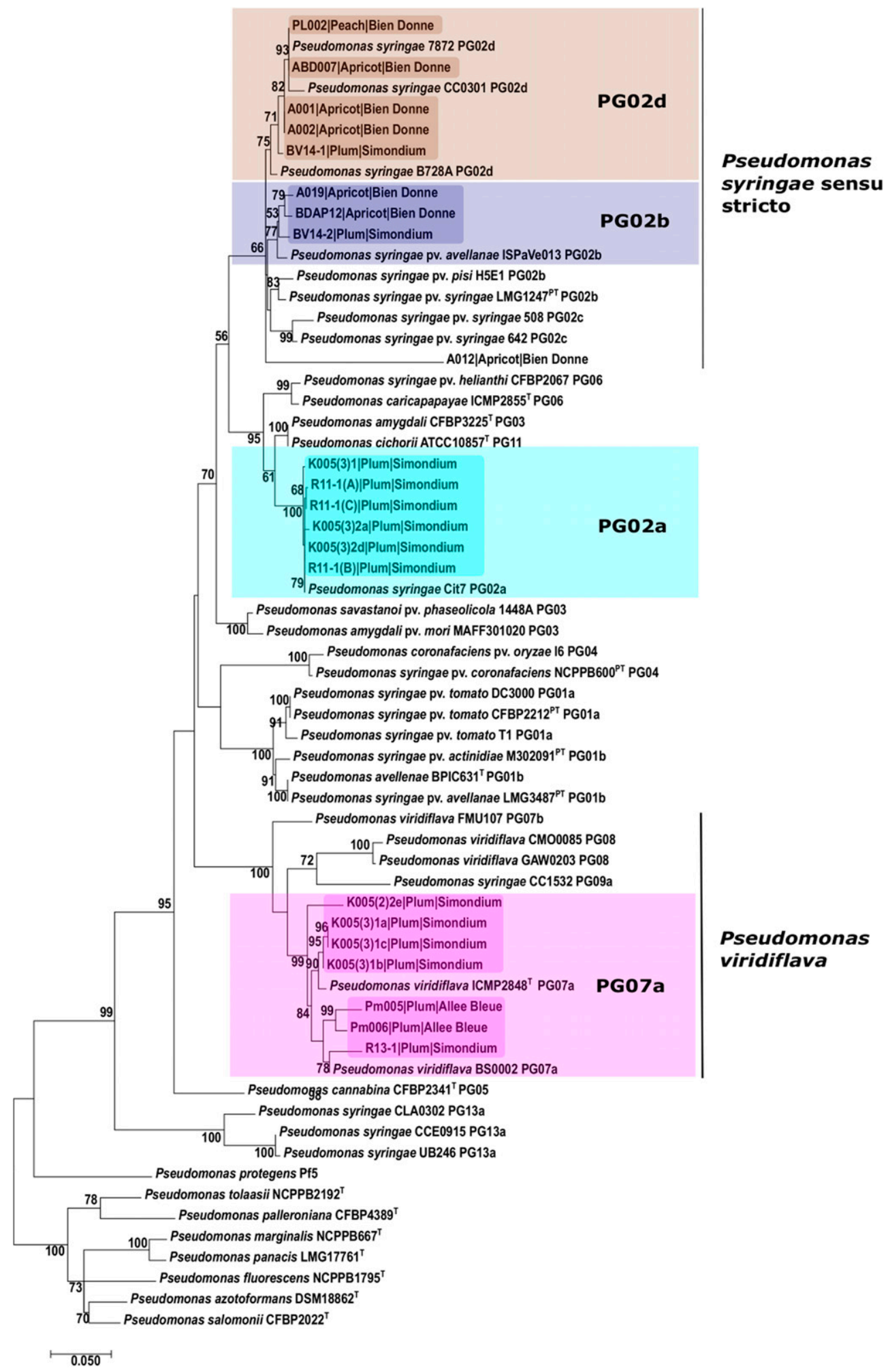

Fig. 2. A maximum likelihood tree representing the concatenated phylogeny based on cts, gapA, gyrB, and $r p o D$ gene sequences of the Pseudomonas isolates and reference strains in the $P$. syringae species complex as previously shown in Berge et al. (2014). Bootstrap values after 1,000 replicates are indicated as percentages (only values $\geq 50$ are shown). Pseudomonas protegens Pf5 was included as the outgroup. The scale bar represents the number of substitutions per site. 
P. syringae pv. syringae $\mathrm{CFBP} 1392^{\mathrm{T}}$, albeit with a low similarity of $61 \%$, than to $P$. viridiflava $\mathrm{CFBP} 2107^{\mathrm{T}}$, which is more closely related to a $P$. syringae sensu stricto strain, A002 (Fig. 5).

Three pseudomonad strains in this study, A001, ABD007, and BV14-1, that were identified as $P$. syringae sensu stricto strains in the MLSA (Fig. 2; PG02d) clustered together with a reference $P$. syringae sensu stricto, $P$. syringae pv. syringae B728a (Fig. 5, $78 \%$ similarity). Similarly, BV14-2, identified as a $P$. syringae sensu stricto phylogroup $2 \mathrm{~b}$ strain, clustered with $100 \%$ similarity with two pathotypes of the same phylogroup, P. syringae pv. pisi NCPPB $2585^{\mathrm{PT}}$ and $P$. syringae pv. coryli NCPPB $4273^{\mathrm{PT}}$ (Fig. 5). In contrast, two of the $P$. syringae sensu stricto strains, A019 and BDAP19, grouped in a separate clade that was distant from any of the known P. syringae sensu stricto pathotypes (Fig. 5, 86\% similarity).

Pathogenicity assays on $P$. domestica and $P$. armeniaca seedlings. The pathogenicity of 11 representative pseudomonad strains from the two major phylogroups identified in this study (Fig. 2; phylogroups 2 and 7) was determined on apricot seedlings, 'Soldonna' and plum seedlings, 'Sapphire' and 'Songold'. We found that all representative pseudomonad strains were pathogenic on both apricot and plum seedlings (Fig. 6A to 6D and Fig. 7A to 7D). The pseudomonad strains were able to induce symptoms of bacterial

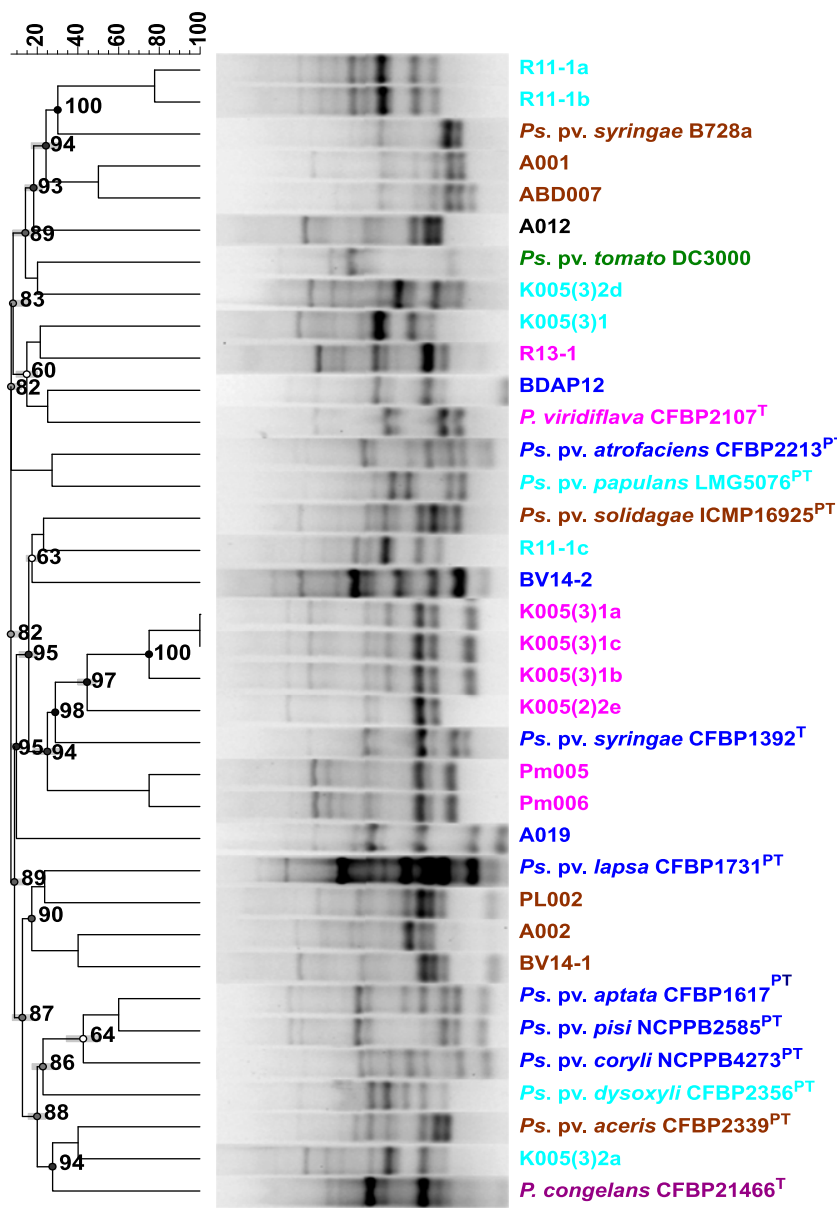

Fig. 3. Unweighted pair group method with arithmetic mean (UPGMA) tree representing the BOX-PCR fingerprint profiles of stone fruit and pathotype strains in $P$. syringae sensu stricto and $P$. viridiflava. The dendrogram was produced from distance matrix of BOX fingerprint profiles calculated via Jaccard similarity coefficient. The cophenetic correlation was used to calculate the consistency of the clusters, and the values are indicated as percentages on the branches of each cluster. Type strains are denoted by superscript T, pathotype strains denoted by superscript PT. Color scheme: Pseudomonas syringae sensu stricto strains are shown in teal (phylogroup 2a), blue (phylogroup 2b), purple (phylogroup 2c), brown (phylogroup 2d), and black (unidentified clade in phylogroup 2); $P$. viridiflava strains are shown in pink (phylogroup 7a), and $P$. syringae pv. tomato (phylogroup 1a) is shown in dark green. canker such as brown discoloration of the inner tissue and gummosis (Fig. 6D and Fig. 7A, C, and D). Interestingly, shoot dieback was observed for all inoculated apricot seedlings (Supplementary Fig. S1), and complete dieback was observed in only a single apricot replicate inoculated with pseudomonad strains, A002 (phylogroup 2d, $P$. syringae) and K005(2)2e (phylogroup 7a, P. viridiflava), independently. Also, no symptoms were observed for the negative control replicates. Furthermore, the pseudomonad strains recovered from lesions of the inoculated apricot and plum seedlings had the same BOX-PCR fingerprint profiles as the inoculum strains, proving Koch's postulates (result not shown).

\section{Discussion}

The objective of this study was to identify bacterial strains isolated from stone fruit trees showing symptoms of bacterial canker in the Western Cape province of South Africa. Based on the MLSA maximum likelihood tree, two species groups within $P$. syringae sensu lato were found to be associated with bacterial canker of stone fruit trees, namely $P$. syringae sensu stricto and $P$. viridiflava. To the best of our knowledge, this is the first report of $P$. viridiflava isolated from plum trees showing symptoms of bacterial canker.

The only known causal agents of bacterial canker on stone fruit trees in South Africa have been P. syringae pv. syringae and $P$. syringae pv. morsprunorum (Roos and Hattingh 1983, 1986). Pseudomonas viridiflava associated with bacterial canker has been reported only on kiwifruit (Actinidia deliciosa) and apricot (Bartoli et al. 2014; Parisi et al. 2019). Pseudomonas viridiflava is considered to

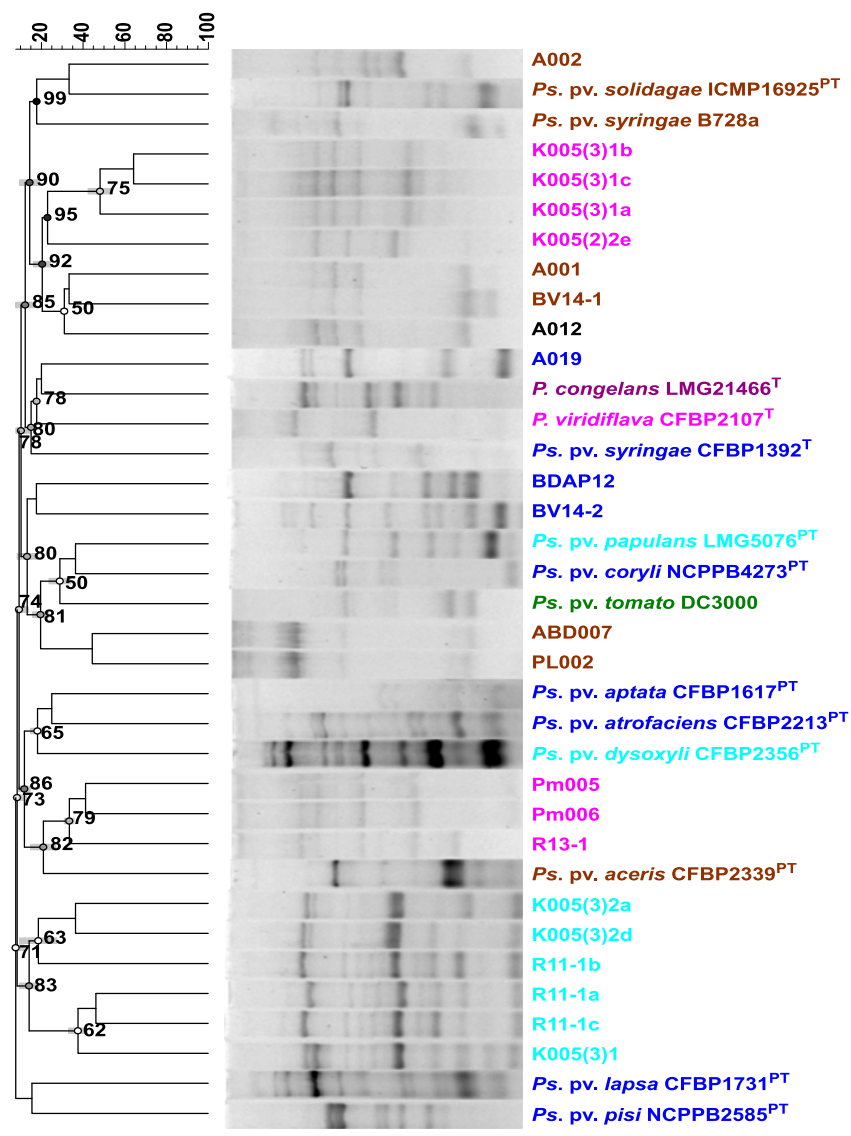

Fig. 4. UPGMA tree representing the REP-PCR fingerprint profiles of stone fruit and pathotype strains in $P$. syringae sensu stricto and $P$. viridiflava. The dendrogram was produced from distance matrix of REP fingerprint profiles calculated via Jaccard similarity coefficient. The cophenetic correlation was used to calculate the consistency of the clusters, and the values are indicated as percentages on the branches of each cluster. Type strains are denoted by superscript $T$, pathotype strains denoted by superscript PT. Color scheme: Pseudomonas syringae sensu stricto strains are shown in teal (phylogroup 2a), blue (phylogroup 2b), purple (phylogroup 2c), brown (phylogroup 2d), and black (unidentified clade in phylogroup 2); $P$. viridiflava strains are shown in pink (phylogroup 7a), and $P$. syringae pv. tomato (phylogroup 1a) is shown in dark green. 


\section{ำㅇํㅇㅇำ}

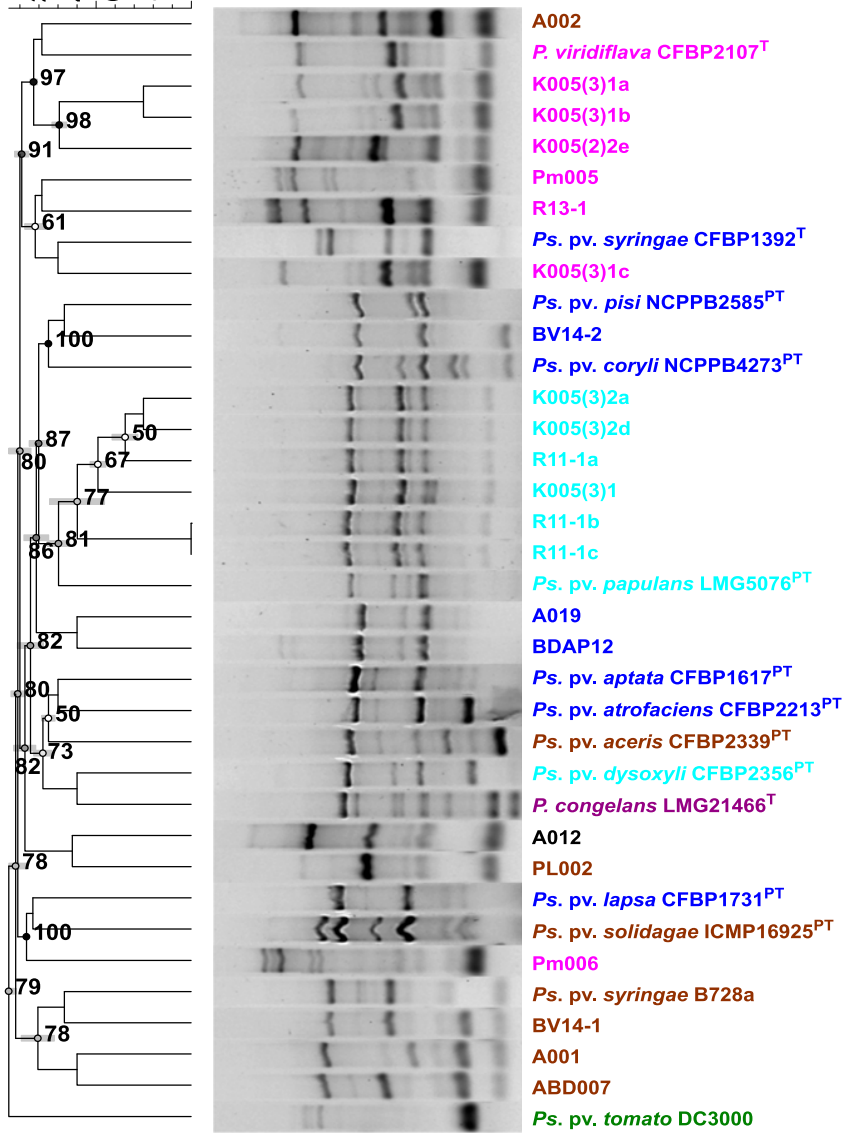

Fig. 5. UPGMA tree representing the ERIC-PCR fingerprint profiles of stone fruit and pathotype strains in $P$. syringae sensu stricto and $P$. viridiflava. The dendrogram was produced from distance matrix of ERIC fingerprint profiles calculated via Jaccard similarity coefficient. The cophenetic correlation was used to calculate the consistency of the clusters, and the values are indicated as percentages on the branches of each cluster. Type strains are denoted by superscript T, pathotype strains denoted by superscript PT. Color scheme: $P$. syringae sensu stricto strains are shown in teal (phylogroup 2a), blue (phylogroup 2b), purple (phylogroup 2c), brown (phylogroup 2d), and black (unidentified clade in phylogroup 2); P. viridiflava strains are shown in pink (phylogroup 7a), and P. syringae pv. tomato (phylogroup 1 a) is shown in dark green. be an opportunistic pathogen that causes foliar diseases of vegetable crops, fruit trees, and aromatic herbs (Billing 1970; Burkholder 1930; Jakob et al. 2002; Wilkie et al. 1973).

The co-occurrence of isolates from other bacterial genera alongside Pseudomonas isolates, in symptomatic twigs of stone fruit trees, suggests that there could be an interaction between these populations, whose mechanism has yet to be studied. Previous studies have reported the existence of such pathogen-pathogen or pathogen-nonpathogen (i.e., endophytes) interactions in infections sites of plant hosts (Lamichhane and Venturi 2015). For example, bigger knots and increased severity of the olive knot disease were observed in the presence of the pathogen Pseudomonas savastanoi pv. savastanoi and the predominant endophytes, namely Pantoea agglomerans, Erwinia oleae, and Erwinia toletana, in the same ecological niche (Buonaurio et al. 2015). Similarly, bacterial species such as Pseudomonas corrugata and Pseudomonas mediterranea, associated with tomato pith necrosis, though able to cause disease symptoms alone, were shown to act synergistically in exacerbating pith necrotic lesions on tomato fruits (Moura et al. 2005).

The occurrence of two phylogenetic groups within $P$. syringae sensu lato affecting stone fruit trees in South Africa was further corroborated by the phenotypic characteristics based on the LOPAT diagnostic assays (Lelliott et al. 1966). These assays have become a standard practice to rapidly distinguish between fluorescent pseudomonad strains, with the pectolytic activity on potato being the primary distinguishing factor (González et al. 2003; Sarris et al. 2012; Timilsina et al. 2017a, 2017b). Some pseudomonad strains are unable to produce fluorescent pigments on KMB, as was the case with eight Pseudomonas isolates in this study (Table 2). Also, the original strain of $P$. syringae pv. syringae $\mathrm{B} 728 \mathrm{a}$ is known to produce pyoverdine, a fluorescent pigment, on KMB, but the particular isolate used in this study did not fluoresce on KMB (Feil et al. 2005), indicating that the isolate used was a mutant that probably no longer produces the fluorescent siderophore. Interestingly, the peptone, gelatin, sucrose (PGS) medium supplemented with iron-binding substances at lower concentrations was shown to increase fluorescent pigment production of Pseudomonas isolates that were otherwise nonfluorescent on KMB and casaminic, sucrose, gelatin agar (Lamichhane and Varvaro 2013). Taken together, the regular use of PGS medium, inclusive of chelating agents that can bind metal ions in the medium, will provide accurate detection of fluorescent pigments produced by Pseudomonas spp.

The Pseudomonas isolates from this study separated into two LOPAT groups: LOPAT group Ia, the true $P$. syringae strains, and LOPAT group II, a group of $P$. viridiflava strains. The majority of the pseudomonad strains identified as LOPAT group Ia $(P$. syringae sensu stricto) could not cause soft rot on potato slices, whereas the

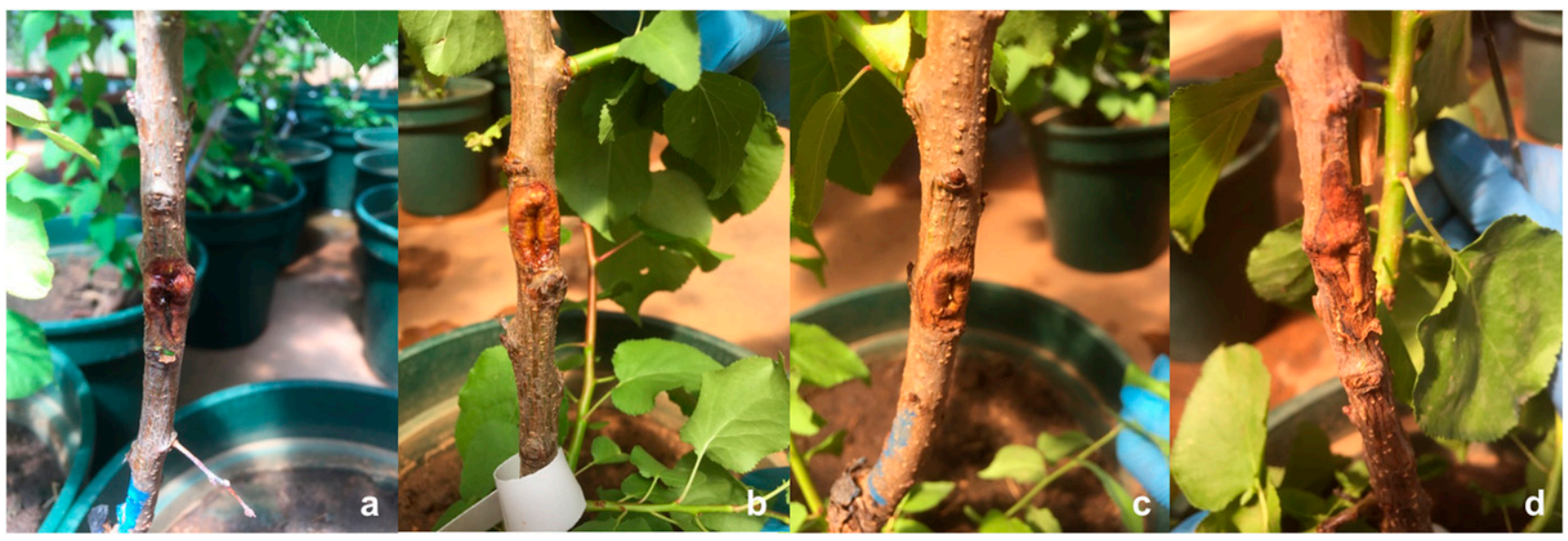

Fig. 6. Symptoms caused by pseudomonad isolates infiltrated through wounding into 1-year-old apricot stems of cultivar 'Soldonna'. a and b, Gummosis exuding from stems inoculated with $P$. syringae K005(3)2d and $P$. viridiflava K005(3)1c, respectively. c and d, Brown discoloration of the bark with water-soaked margins caused by $P$. syringae BDAP12 and $P$. syringae A002, respectively. Pictures were taken at 30 days after inoculation. 

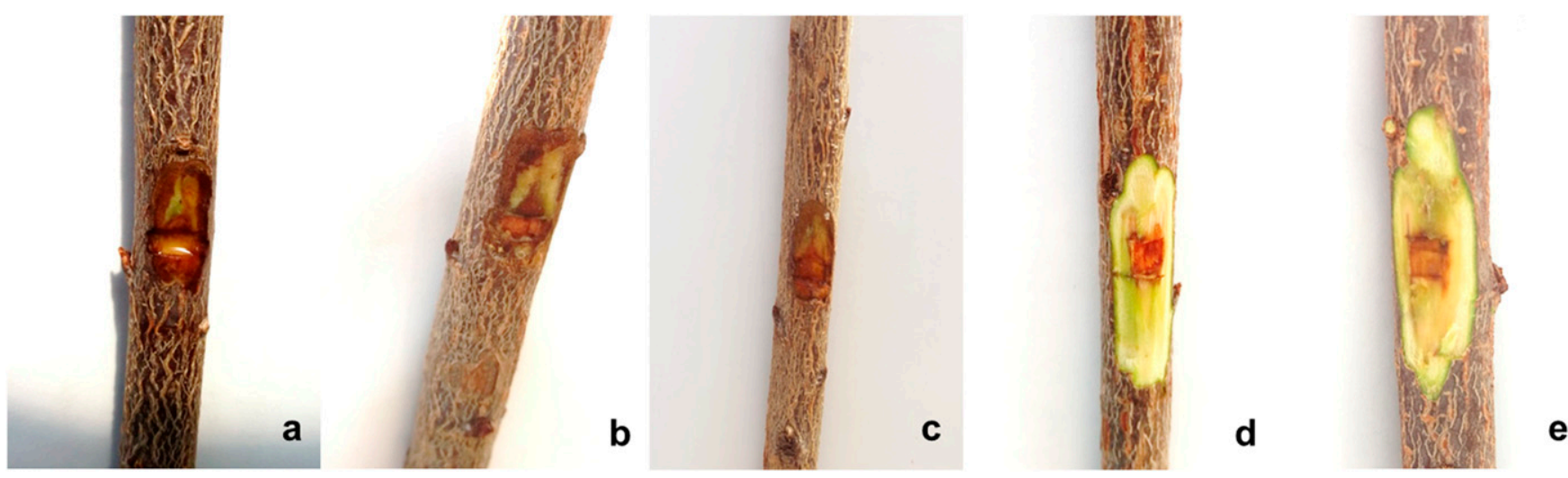

Fig. 7. Symptoms caused by pseudomonad isolates infiltrated through wounding of the stems of 1-year-old plum seedlings of cultivars 'Sapphire' and 'Songold'. a, Brown discoloration accompanied by gummosis exuding from the inoculation site, caused by Pseudomonas syringae R11-1a. $\mathbf{b}$ and $\mathbf{c}$, Brown discoloration of the inner bark, caused by $P$. syringae BV14-2 and P. viridiflava K005(3)1c, respectively. d, Brown discoloration of the inner bark only at the site of inoculation P. syringae BV14-1. e, Light brown discoloration on the negative control is a result of wounding. Pictures were taken at 30 days after inoculation.

strains identified as LOPAT group II ( $P$. viridiflava) were able to induce soft rot on potato slices (Table 1). However, it has been previously shown that the induction of pectolytic activity on potato is not a stable feature of all $P$. viridiflava strains; that is, some $P$. viridiflava strains are known not to induce soft rot on potato (Bartoli et al. 2014). The lack of pectolytic activity among $P$. viridiflava strains has been attributed to the occurrence of phase variation, which is likely to interfere with the expression of pectolytic activity, thus making soft rot on potato an unpredictable diagnostic feature in this group (Bartoli et al. 2014; Jakob et al. 2007).

Interestingly, four LOPAT group II ( $P$. viridiflava) isolates did not induce a hypersensitive response on tobacco, despite their ability to induce pectolytic activity on potato and bacterial canker symptoms on apricot and plum seedlings (Figs. 6 and 7). It has been reported that $P$. viridiflava strains harbor two types of T3SS pathogenicity islands (S-PAI and T-PAI) known to encode a functional T3SS hrc/hrp cluster (Araki et al. 2006). It has been previously shown that a lack of the $h r p L$ gene, which is present on both S-PAI and T-PAI, attenuates pathogenicity on Arabidopsis (Jakob et al. 2007). However, some $P$. viridiflava strains were shown to still induce symptoms on cantaloupe despite a lack of a complete set of $h r c / h r p$ effectors on S/TPAIs to render a functional T3SS, except for three effectors, $a v r E$, $h o p A 1$, and $s h c F$, which appear to abolish pathogenicity if absent (Bartoli et al. 2014). Moreover, the $P$. viridiflava strains that were shown to have the $a v r E$ effector had pectolytic activity, indicating that the virulence of the four $P$. viridiflava strains identified in this study is independent of the presence of a complete T3SS.

The clustering of ERIC and REP fingerprint profiles showed congruency with MLSA phylogeny, whereas the BOX fingerprint profiles did not. However, only in the REP dendrogram were two clusters of pseudomonad strains isolated from symptomatic stone fruit trees grouped correctly with previously identified pathotypes. In both the ERIC and BOX dendrograms, the type strain of $P$. syringae pv. syringae, CFBP1392 ${ }^{\mathrm{T}}$, was shown to cluster with $P$. viridiflava strains. Previous studies have shown the BOX and ERIC elements to be useful diagnostic tools for providing evidence to support phylogenetic delimitation of pseudomonad strains into respective $P$. syringae groups (Ahmadi et al. 2017; Bull et al. 2011; Newberry et al. 2016). In this study, we showed that the REP element was instead a more robust diagnostic tool to rapidly identify pseudomonad strains isolated from symptomatic stone fruit trees in South Africa.

We showed that the pseudomonad strains isolated from symptomatic stone fruit trees were able to induce bacterial canker symptoms on both apricot and plum seedlings, indicating that these strains may potentially lack host specificity on Prunus hosts. Pathogenicity has been tested with laboratory-prepared inoculum of a large number of $P$. syringae strains on both annual and perennial plants. These tests demonstrated a lack of host specificity for strains in the $P$. syringae species complex in laboratory studies (Morris et al. 2019). A few examples include $P$. syringae pv. morsprunorum race 1 causing bacterial canker on plum and sweet cherry (Hulin et al. 2018) and $P$. syringae pvs., aptata, atrofaciens, coryli, lapsa, pisi, and syringae, known to cause angular leaf spots on cucurbit hosts (Morris et al. 2019; Newberry et al. 2016). However, comprehensive host range tests on other Prunus spp. are needed to prove our hypothesis of nonhost specificity among pseudomonad strains infecting Prunus hosts.

In conclusion, we have shown that two Pseudomonas species are associated with bacterial canker of stone fruit trees in South Africa, namely $P$. syringae sensu stricto and $P$. viridiflava. This study is the first report of $P$. viridiflava isolated from plum trees showing symptoms of bacterial canker, suggesting that this bacterial species is a potentially emerging pathogen of stone fruit trees in South Africa. The findings of this study contribute to our understanding of the epidemiology of bacterial canker of stone fruit trees in South Africa, which has implications for disease surveillance and management practices.

\section{Acknowledgments}

The authors thank staff at the DNA sequencing facility at the University of Pretoria for assistance with DNA sequencing and staff members of the Forestry and Agricultural Biotechnology Institute and of the Centre for Microbial Ecology and Genomics for the administrative assistance during the study period.

\section{Author-Recommended Internet Resource}

https://www.hortgro.co.za

\section{Literature Cited}

Ahmadi, S., Harighi, B., and Abdollahzadeh, J. 2017. Phylogenetic relationships of fluorescent Pseudomonad isolates associated with bacterial canker of stone fruit trees in Kurdistan province, Iran. Eur. J. Plant Pathol. 150:679-689.

Araki, H., Tian, D., Goss, E. M., Jakob, K., Halldorsdottir, S. S., Kreitman, M., and Bergelson, J. 2006. Presence/absence polymorphism for alternative pathogenicity islands in Pseudomonas viridiflava, a pathogen of Arabidopsis. Proc. Natl. Acad. Sci. USA 103:5887-5892.

Ark, P. 1939. Bacterial leaf spot of maple. Phytopathology 29:968-970.

Ark, P. 1940. Bacterial stalk rot of field corn caused by Phytomonas lapsa, n. sp. Phytopathology 30:1.

Bartoli, C., Berge, O., Monteil, C. L., Guilbaud, C., Balestra, G. M., Varvaro, L. Jones, C., Dangl, J. L., Baltrus, D. A., and Sands, D. C. 2014. The Pseudomonas viridiflava phylogroups in the $P$. syringae species complex are characterized by genetic variability and phenotypic plasticity of pathogenicity-related traits. Environ. Microbiol. 16:2301-2315.

Behrendt, U., Ulrich, A., and Schumann, P. 2003. Fluorescent pseudomonads associated with the phyllosphere of grasses; Pseudomonas trivialis sp. nov., Pseudomonas poae sp. nov. and Pseudomonas congelans sp. nov. Int. J. Syst. Evol. Microbiol. 53:1461-1469.

Berge, O., Monteil, C. L., Bartoli, C., Chandeysson, C., Guilbaud, C., Sands, D. C., and Morris, C. E. 2014. A user's guide to a data base of the diversity of Pseudomonas syringae and its application to classifying strains in this phylogenetic complex. PLoS One 9:e105547. 
Billing, E. 1970. Pseudomonas viridiflava (Burkholder, 1930; Clara 1934). J. Appl. Microbiol. 33:492-500.

Brown, N. A., and Jamieson, C. O. 1913. A bacterium causing a disease of sugarbeet and nasturtium leaves. J. Agric. Res. 1:189-210.

Bull, C., De Boer, S., Denny, T., Firrao, G., Fischer-Le Saux, M., Saddler, G., Scortichini, M., Stead, D., and Takikawa, Y. 2010. Comprehensive list of names of plant pathogenic bacteria, 1980-2007. J. Plant Pathol. 92:551592

Bull, C. T., Clarke, C. R., Cai, R., Vinatzer, B. A., Jardini, T. M., and Koike, S. T. 2011. Multilocus sequence typing of Pseudomonas syringae sensu lato confirms previously described genomospecies and permits rapid identification of $P$. syringae pv. coriandricola and $P$. syringae pv. apii causing bacterial leaf spot on parsley. Phytopathology 101:847-858.

Bull, C. T., and Koike, S. T. 2015. Practical benefits of knowing the enemy: modern molecular tools for diagnosing the etiology of bacterial diseases and understanding the taxonomy and diversity of plant-pathogenic bacteria. Annu. Rev. Phytopathol. 53:157-180.

Bultreys, A., and Kaluzna, M. 2010. Bacterial cankers caused by Pseudomonas syringae on stone fruit species with special emphasis on the pathovars syringae and morsprunorum race 1 and race 2. J. Plant Pathol. 92:S21-S33.

Buonaurio, R., Moretti, C., da Silva, D. P., Cortese, C., Ramos, C., and Venturi, V. 2015. The olive knot disease as a model to study the role of interspecies bacterial communities in plant disease. Front. Plant Sci. 6:434.

Burkholder, W. H. 1930. The bacterial diseases of the bean. A comparative study. (Cornell). Agr. Exp. Sta. Mem. 127:59-77.

Crosse, J. 1966. Epidemiological relations of the pseudomonad pathogens of deciduous fruit trees. Annu. Rev. Phytopathol. 4:291-310.

Cuppels, D. A. 1986. Generation and characterization of Tn5 insertion mutations in Pseudomonas syringae pv. tomato. Appl. Environ. Microbiol. 51:323-327.

Dhanvantari, B. 1977. A taxonomic study of Pseudomonas papulans Rose 1917. New Zeal. J. Agr. Res. 20:557-561.

Dutta, B., Gitaitis, R., Agarwal, G., Coutinho, T., and Langston, D. 2018. Pseudomonas coronafaciens sp. nov., a new phytobacterial species diverse from Pseudomonas syringae. PLoS One 13:e0208271.

Feil, H., Feil, W. S., Chain, P., Larimer, F., DiBartolo, G., Copeland, A., Lykidis, A., Trong, S., Nolan, M., and Goltsman, E. 2005. Comparison of the complete genome sequences of Pseudomonas syringae pv. syringae B728a and pv. tomato DC3000. Proc. Natl. Acad. Sci. USA 102:11064-11069.

Gardan, L., Shafik, H., Belouin, S., Broch, R., Grimont, F., and Grimont, P. 1999. DNA relatedness among the pathovars of Pseudomonas syringae and description of Pseudomonas tremae sp. nov. and Pseudomonas cannabina sp. nov.(ex Sutic and Dowson 1959). Int. J. Syst. Evol. Microbiol. 49: 469-478.

Gomila, M., Busquets, A., Mulet, M., García-Valdés, E., and Lalucat, J. 2017. Clarification of taxonomic status within the Pseudomonas syringae species group based on a phylogenomic analysis. Front. Microbiol. 8:2422.

González, A. J., Rodicio, M. R., and Mendoza, M. C. 2003. Identification of an emergent and atypical Pseudomonas viridiflava lineage causing bacteriosis in plants of agronomic importance in a Spanish region. Appl. Environ. Microbiol. 69:2936-2941.

Hall, T. A. 1999. BioEdit: a user-friendly biological sequence alignment editor and analysis program for Windows 95/98/NT. Nucleic Acids Symp. Ser. 41:95-98.

Hattingh, M., Roos, I., and Mansvelt, E. 1989. Infection and systemic invasion of deciduous fruit trees by Pseudomonas syringae in South Africa. Plant Dis. 73: 784-789.

Hongoh, Y., Yuzawa, H., Ohkuma, M., and Kudo, T. 2003. Evaluation of primers and PCR conditions for the analysis of 16S rRNA genes from a natural environment. FEMS Microbiol. Lett. 221:299-304.

Hulin, M. T., Mansfield, J. W., Brain, P., Xu, X., Jackson, R. W., and Harrison, R. 2018. Characterization of the pathogenicity of strains of Pseudomonas syringae towards cherry and plum. Plant Pathol. 67:1177-1193.

Hwang, M. S., Morgan, R. L., Sarkar, S. F., Wang, P. W., and Guttman, D. S. 2005. Phylogenetic characterization of virulence and resistance phenotypes of Pseudomonas syringae. Appl. Environ. Microbiol. 71:5182-5191.

Jaccard, P. 1901. Distribution de la flore alpine dans le bassin des Dranses et dans quelques régions voisines. Bull. Soc. Vaud. Sci. Nat. 37:241-272.

Jakob, K., Goss, E. M., Araki, H., Van, T., Kreitman, M., and Bergelson, J. 2002. Pseudomonas viridiflava and P. syringae-natural pathogens of Arabidopsis thaliana. Mol. Plant-Microbe Interact. 15:1195-1203.

Jakob, K., Kniskern, J. M., and Bergelson, J. 2007. The role of pectate lyase and the jasmonic acid defense response in Pseudomonas viridiflava virulence. Mol. Plant-Microbe Interact. 20:146-158.

Janse, J., Rossi, P., Angelucci, L., Scortichini, M., Derks, J., Akkermans, A., De Vrijer, R., and Psallidas, P. 1996. Reclassification of Pseudomonas syringae pv. avellanae as Pseudomonas avellanae spec. nov, the bacterium causing canker of hazelnut (Corylus avellana L.). Syst. Appl. Microbiol. 19:589-595

Kałużna, M., Willems, A., Pothier, J. F., Ruinelli, M., Sobiczewski, P., and Puławska, J. 2016. Pseudomonas cerasi sp. nov.(non Griffin, 1911) isolated from diseased tissue of cherry. Syst. Appl. Microbiol. 39:370-377.

Katoh, K., Misawa, K., Kuma, K. i., and Miyata, T. 2002. MAFFT: a novel method for rapid multiple sequence alignment based on fast Fourier transform. Nucleic Acids Res. 30:3059-3066.
Katoh, K., and Standley, D. M. 2013. MAFFT multiple sequence alignment software version 7: improvements in performance and usability. Mol. Biol. Evol. 30:772-780.

King, E. O., Ward, M. K., and Raney, D. E. 1954. Two simple media for the demonstration of pyocyanin and fluorescein. J. Lab. Clin. Med. 44: 301-307.

Kumar, S., Stecher, G., and Tamura, K. 2016. MEGA7: Molecular Evolutionary Genetics Analysis version 7.0 for bigger datasets. Mol. Biol. Evol. 33: $1870-1874$.

Lamichhane, J., and Varvaro, L. 2013. A new medium for the detection of fluorescent pigment production by pseudomonads. Plant Pathol. 62: 624-632.

Lamichhane, J. R., Messéan, A., and Morris, C. E. 2015. Insights into epidemiology and control of diseases of annual plants caused by the Pseudomonas syringae species complex. J. Gen. Plant Pathol. 81:331-350.

Lamichhane, J. R., Varvaro, L., Parisi, L., Audergon, J.-M., and Morris, C. E. 2014. Disease and frost damage of woody plants caused by Pseudomonas syringae: seeing the forest for the trees. Adv. Agron. 126:235-295.

Lamichhane, J. R., and Venturi, V. 2015. Synergisms between microbial pathogens in plant disease complexes: a growing trend. Front. Plant Sci. 6:385.

Lane, D. 1991. 16S/23S rRNA sequencing. Pages 115-175 in: Nucleic Acid Techniques in Bacterial Systematics. E. Stackebrandt and M. Goodfellow, eds. John Wiley \& Sons, New York.

Lelliott, R. A., Billing, E., and Hayward, A. C. 1966. A determinative scheme for the fluorescent plant pathogenic pseudomonads. J. Appl. Bacteriol. 29:470-489.

Loper, J. E., and Lindow, S. E. 1987. Lack of evidence for the in situ fluorescent pigment production by Pseudomonas syringae pv. syringae on bean leaf surfaces. Phytopathology 77:1449-1454

Louws, F. J., Fulbright, D. W., Stephens, C. T., and De Bruijn, F. 1994. Specific genomic fingerprints of phytopathogenic Xanthomonas and Pseudomonas pathovars and strains generated with repetitive sequences and PCR. Appl. Environ. Microbiol. 60:2286-2295.

McCulloch, L. 1920. Basal glume rot of wheat. J. Agric. Res. 18:543-552

Ménard, M., Sutra, L., Luisetti, J., Prunier, J., and Gardan, L. 2003. Pseudomonas syringae pv. avii (pv. nov.), the causal agent of bacterial canker of wild cherries (Prunus avium) in France. Eur. J. Plant Pathol. 109:565-576.

Morris, C. E., Lamichhane, J. R., Nikolić, I., Stanković, S., and Moury, B. 2019 The overlapping continuum of host range among strains in the Pseudomonas syringae complex. BMC Phytopathol. Res. 1:4.

Moura, M., Jacques, M., Brito, L., Mourão, I., and Duclos, J. 2005. Tomato pith necrosis (TPN) caused by $P$. corrugata and $P$. mediterranea: severity of damages and crop loss assessment. Acta Hortic.: 365-372.

Newberry, E., Jardini, T., Rubio, I., Roberts, P., Babu, B., Koike, S., Bouzar, H., Goss, E., Jones, J., and Bull, C. 2016. Angular leaf spot of cucurbits is associated with genetically diverse Pseudomonas syringae strains. Plant Dis. 100:1397-1404

Parisi, L., Morgaint, B., Blanco-Garcia, J., Guilbaud, C., Chandeysson, C., Bourgeay, J., Moronvalle, A., Brun, L., Brachet, M., and Morris, C. 2019 Bacteria from four phylogroups of the Pseudomonas syringae complex can cause bacterial canker of apricot. Plant Pathol. 68:1249-1258.

Parkinson, N., Bryant, R., Bew, J., and Elphinstone, J. 2011. Rapid phylogenetic identification of members of the Pseudomonas syringae species complex using the rpoD locus. Plant Pathol. 60:338-344.

Psallidas, P., and Pamagopoulos, C. 1975. new bacteriosis of almond caused by Pseudomonas amygdali sp. nov. Ann. Inst. Phytopathol. Benaki 11:94-108.

Rademaker, J., Louws, F. J., and De Bruijn, F. 1998. Characterization of the diversity of ecologically important microbes by rep-PCR genomic fingerprinting Pages 1-26 in: Molecular Microbial Ecology Manual I, supplement 3. A.D.L. Akkermans, J.D. van Elsas, and F.J. de Bruijn, eds. Kluwer Academic Publishers, Dordrecht, The Netherlands.

Robbs, C. 1956. Uma nova doença bacteriana do mamoeiro (Carica papaya L.) Rev. Soc. Bras. Agr. 12:73-76.

Roos, I. M. M., and Hattingh, M. J. 1983. Fluorescent pseudomonads associated with bacterial canker of stone fruit in South Africa. Plant Dis. 67:1267-1269.

Roos, I. M., and Hattingh, M. 1986. Resident populations of Pseudomonas syringae on stone fruit tree leaves in South Africa. Phytophylactica 18:55-58.

Rose, D. H. 1917. Blister spot of apples and its relation to a disease of apple bark. Phytopathology 7:198-208.

Sackett, W. G. 1916. A bacterial stem blight of field and garden peas. Colo. Agric Exp. Stn. Bull. 218:1-43.

Sarkar, S. F., and Guttman, D. S. 2004. Evolution of the core genome of Pseudomonas syringae, a highly clonal, endemic plant pathogen. Appl. Environ. Microbiol. 70:1999-2012.

Sarris, P. F., Trantas, E. A., Mpalantinaki, E., Ververidis, F., and Goumas, D. E. 2012. Pseudomonas viridiflava, a multi host plant pathogen with significant genetic variation at the molecular level. PLoS One 7:e36090.

Sato, M., Watanabe, K., and Sato, Y. 2001. Pseudomonas syringae pv. solidagae pv. nov., the causal agent of bacterial leaf spot of Tall Goldenrod Solidago altissima L. J. Gen. Plant. Pathol. 67:303-308.

Scortichini, M., Rossi, M. P., Loreti, S., Bosco, A., Fiori, M., Jackson, R. W., Stead, D. E., Aspin, A., Marchesi, U., and Zini, M. 2005. Pseudomonas syringae pv. coryli, the causal agent of bacterial twig dieback of Corylus avellana. Phytopathology 95:1316-1324. 
Timilsina, S., Adkison, H., Testen, A. L., Newberry, E. A., Miller, S. A., Paret, M. L., Minsavage, G. V., Goss, E. M., Jones, J. B., and Vallad, G. E. 2017a. A novel phylogroup of Pseudomonas cichorii identified following an unusual disease outbreak on tomato. Phytopathology 107:1298-1304.

Timilsina, S., Minsavage, G. V., Preston, J., Newberry, E. A., Paret, M. L., Goss, E. M., Jones, J. B., and Vallad, G. E. 2017b. Pseudomonas floridensis sp. nov., a bacterial pathogen isolated from tomato. Int. J. Syst. Evol. Microbiol. 68:64-70.

van Hall, C. J. J. 1902. Bijdragen tot de kennis der Bakterieele Plantenziekten. Companyöperatieve drukkerij-vereeniging "Plantijn". Inaugural dissertation, Amsterdam, p. 198.

Versalovic, J., Koeuth, T., and Lupski, R. 1991. Distribution of repetitive DNA sequences in eubacteria and application to fingerprinting of bacterial genomes. Nucleic Acids Res. 19:6823-6831.
Versalovic, J., Schneider, M., De Bruijn, F., and Lupski, J. R. 1994. Genomic fingerprinting of bacteria using repetitive sequence-based polymerase chain reaction. Methods Mol. Cell. Biol. 5:25-40.

Wilkie, J. P., Dye, D. W., and Watson, D. R. W. 1973. Further hosts of Pseudomonas viridiflava. N. Zeal. J. Agr. Res. 16:315-323.

Wilson, E. 1953. Pages 722-729 in: Bacterial Canker of Stone Fruits. Year BookAgr. U.S. Department of Agriculture, Washington, DC.

Young, J. 1988. Pseudomonas syringae pv. persicae from nectarine, peach, and Japanese plum in New Zealand 1. EPPO Bull. 18:141-151.

Young, J. 1991. Pathogenicity and identification of the lilac pathogen, Pseudomonas syringae pv. syringae van Hall 1902. Ann. Appl. Biol. 118:283-298.

Young, J., Dye, D., Bradbury, J., Panagopoulos, C., and Robbs, C. 1978. A proposed nomenclature and classification for plant pathogenic bacteria. N. Z. J. Agric. Res. 21:153-177. 